\title{
Value of Glut-1 and Koc Markers in the Differential Diagnosis of Reactive Mesothelial Hyperplasia, Malignant Mesothelioma and Pulmonary Adenocarcinoma
}

\author{
Reaktif Mezotel Hiperplazisi, Malign Mezotelyoma ve Akciğer \\ Adenokarsinomu Ayırıcı Tanısında Glut-1 ve Koc'un Yeri
}

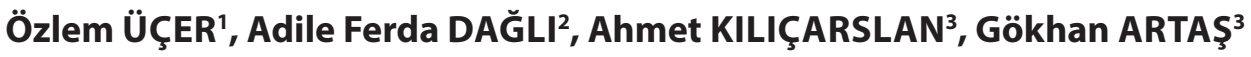 \\ 'Department of Pathology, Bingöl State Hospital, BINGÖL, TURKEY \\ Department of Pathology, ${ }^{2}$ Inönü University, Faculty of Medicine, MALATYA, TURKEY, ${ }^{3}$ FIrat University, Faculty of Medicine, ELAZIĞ, TURKEY
}

\begin{abstract}
Objective: Malignant mesothelioma (MM) is a primary malignant tumor developing from mesothelial cells lining the serosal surfaces and particularly the pleura, and has a very poor prognosis. It may display a variety of histological patterns and has a wide spectrum of cytomorphological characteristics, causing problems in its differential diagnosis from lung adenocarcinomas and sometimes from benign mesothelial proliferations. Immunohistochemical examination is the most useful method for this distinction. In our study, we aimed to determine the value of glucose transporter isoform-1 (GLUT-1) and $\mathrm{K}$ homology domain-containing protein (KOC) markers in the differential diagnosis of reactive mesothelial hyperplasia, malignant mesothelioma and lung adenocarcinoma.
\end{abstract}

Material and Method: Our study included 30 samples of malignant mesothelioma, 30 samples of pulmonary adenocarcinoma and 30 samples of reactive mesothelial hyperplasia selected from the archives of the Firat University Hospital's Pathology Department Laboratory. The samples were applied GLUT-1 and KOC markers by immunohistochemistry and the place of these markers in the differential diagnosis was examined.

Results: GLUT-1 was found positive in $80 \%$ of malignant mesothelioma cases, $83.3 \%$ of adenocarcinoma cases and $6.6 \%$ of reactive mesothelial hyperplasia cases. KOC was positive in $83.3 \%$ of malignant mesothelioma cases, $76.6 \%$ of adenocarcinoma cases and $46.6 \%$ of reactive mesothelial hyperplasia cases. There was no statistically significant difference between malignant mesothelioma and lung adenocarcinoma cases in terms of the diffuseness and intensity of staining with GLUT-1, whereas a significant difference was established when these groups were compared with reactive mesothelial hyperplasia cases. However, the KOC staining diffuseness and intensity results were similar to those obtained with GLUT-1.

Conclusion: In conclusion, GLUT-1 and KOC markers do not differentiate malignant mesotheliomas from pulmonary adenocarcinomas but can be useful in differentiating reactive mesothelial hyperplasia from malignant mesothelioma and lung adenocarcinoma.

Key Words: Mesothelioma, Adenocarcinoma, Mesothelium, Glucose Transporter Type 1, IMP3 protein

(Turk Patoloji Derg 2013, 29:94-100)

Received : 11.12.2012 Accepted : 05.02.2013
ÖZ

Amaç: Malign mezotelyoma, başta plevra olmak üzere serozal yüzeyleri döșeyen mezotel hücrelerinden gelișen, oldukça kötü seyirli primer malign tümördür. Malign mezotelyomanın çok çeşitli histolojik paternler gösterebilmesi ve sitomorfolojik özelliklerinin oldukça geniş olması nedeniyle, akciğer adenokarsinomları ve bazen benign mezotelyal proliferasyonlar ile ayırıcı tanı problemleri yaşanmaktadır. İmmünohistokimyasal inceleme bu ayrım için yardımcı yöntemdir. Çalışmamızda reaktif mezotel hiperplazisi, malign mezotelyoma ve akciğer adenokarsinomu ayırıcı tanısında, glikoz taşıyıcı izoform-1 (GLUT-1) ve K homolog zincir içeren protein (KOC) belirleyicilerinin taşıdığı değeri belirlemeyi amaçladık.

Gereç ve Yöntem: Çalışmamıza Fırat Üniversitesi Hastanesi Patoloji Anabilim Dalı Laboratuvarı arşivinden seçilen 30 malign mezotelyoma, 30 akciğer adenokarsinomu ve 30 reaktif mezotel hiperplazisi örneği alındı. Örneklere immünohistokimyasal olarak GLUT-1 ve KOC belirleyicileri uygulanarak ayırıcı tanıdaki yerleri incelendi.

Bulgular: GLUT-1, malign mezotelyoma örneklerinin \%80'inde, adenokarsinom örneklerinin \% 83,3'ünde ve reaktif mezotel hiperplazisi örneklerinin \%6,6'sında pozitif bulundu. Malign mezotelyoma olgularının \%83,3’ü, akciğer adenokarsinomu olgularının \%76,6'si ve reaktif mezotel hiperplazisi olgularının $\% 46,6$ 'sı KOC pozitifti. GLUT-1 ile boyanma yaygınlığı ve şiddeti açısından, malign mezotelyoma ve akciğer adenokarsinomu olguları arasında istatistiksel olarak anlamlı bir fark yoktu, buna karşılık bu gruplar reaktif mezotel hiperplazisi olgularıyla karşılaştırıldığında anlamlı bir fark bulundu. KOC ile boyanma yaygınlığı ve șiddeti açısından grupların karşılaştırılması ile elde edilen sonuçlar GLUT-1 ile alınan sonuçlara benzerdi.

Sonuç: GLUT-1 ve KOC belirleyicilerinin, malign mezotelyomadan akciğer adenokarsinomlarının ayrımında faydalı olmadığı, ancak reaktif mezotel hiperplazisinin, malign mezotelyoma ve akciğer adenokarsinomundan ayrımında büyük yarar sağlayabileceği kanısına varildı.

Anahtar Sözcükler: Mezotelyoma, Adenokarsinom, Mezotel, Glukoz Taşıyıcı Tip 1, IMP3 protein

Correspondence: Özlem ÜÇER

Bingöl Devlet Hastanesi, Patoloji Bölümü, BİNGÖL, TURKEY

E-mail: ozlem3r@hotmail.com Phone: +90 5337787862 


\section{INTRODUCTION}

Malignant mesothelioma (MM) is a primary malignant tumor developing from mesothelial cells lining the serosal surfaces and particularly the pleura $(1,2)$. It was defined for the first time in South Africa in 1960 by Wagner et al. in relation to asbestos (3). Differential diagnosis of MM is important to provide the appropriate treatment and because of the increase in cases with asbestos-related occupational disease in recent years (4).

It may be difficult to differentiate MM from pulmonary adenocarcinoma (PAC) and benign mesothelial proliferations due to the similarity and large number of varied histological subtypes $(2,4,5,6)$. Many immunohistochemical determinants have so far been studied for the diagnosis of MM and numerous articles have been published for the sensitivity and specificity of each (7). However, many investigators now feel that combinations of two or three antibodies may be useful due to the lack of a specific marker for the diagnosis of MM and the differences in the sensitivities of the antibodies $(5,8,9)$.

The proliferation of cancer cells is a process associated with energy supported by increased glucose metabolism $(10,11)$. This event is realized by glucose transport facilitating proteins whose secretion and activity are regulated by some growth factors and oncogenes (12-14). Theincreased glucose uptake of malignant cells leads to excessive secretion of these carrier proteins (13-15). GLUT-1 (glucose transporter isoform-1) is a member of the glucose transport facilitator family consisting of 14 members and facilitates the entry of glucose into the cell $(12,14,16,17)$. It is physiologically secreted and can be found by IHC in all cells and tissues that use glucose and in particular erythrocyte membranes, the blood-brain barrier and the perineurium of peripheral nerves (11). However, GLUT-1 does not exist or exists in low amounts in most epithelial tissues (12,14,15,17-19).

KOC (K homology domain-containing protein), commonly known as IMP3 (insulin-like growth factor 2 mRNA binding protein 3) in the literature, is an oncofetal RNA-binding protein (20-23). The IMP family plays an important role in the stabilization of mRNA, cell growth, cell proliferation and cell migration during the early stages of embryogenesis $(21,22,24,25)$. It's normal secretion in periods following embryogenesis is limited $(21,23)$.

The aim of this study was to determine the value of GLUT1 and KOC markers in the differential diagnosis between reactive mesothelial hyperplasia $(\mathrm{RMH})$ and PAC.

\section{MATERIAL and METHODS}

Stained preparations and paraffin blocks belonging to a total of 90 patients of which 30 were diagnosed with PAC, 30 with $\mathrm{RMH}$ and 30 with MM (including epithelioid, sarcomatoid and biphasic types) sent to the Furat University Hospital's Medical Pathology Department Laboratory between 1992 and 2011 were included in the study. The archive preparations of the cases were re-examined under the light microscope, their diagnoses verified and new sections prepared from paraffin blocks for IHC application.

Four-micron thick sections obtained from blocks chosen from the samples of ninety cases were processed on the automated staining device (Ventana Medical System, SN: 712299, REF: 750-700, Arizona, USA) for GLUT-1 and KOC staining. Samples of placental tissue were used as positive control for both GLUT-1 and KOC antibodies.

GLUT-1 and KOC stained slides were evaluated under a light microscope. Predominantly membranous but sometimes cytoplasmic staining was considered positive for GLUT-1, and only cytoplasmic staining for KOC.

The percentage of positively stained areas and staining intensity were recorded in all cases for GLUT-1. Membranous staining in more than $50 \%$ of the cells was accepted as $(+++)$, a ratio between $10 \%$ and $50 \%$ as $(++)$, below $10 \%$ as $(+)$ and no staining as negative $(0)(14,23)$. In addition, staining intensity was scored from 1 to 3 as weak $(+)$, moderate $(++)$ and severe $(+++)(23)$.

The percentage of positively stained areas and staining intensity were also recorded in all cases for KOC. Cytoplasmic staining in more than $50 \%$ of the cells was $(+++)$, a ratio between $10 \%$ and $50 \%(++)$, below $10 \%(+)$ and no staining negative (0) (32). Staining intensity was scored from 1 to 3 as weak $(+)$, moderate $(++)$ and severe $(+++)(11,35)$.

Statistical analysis was performed on the computer using the SPSS 19 (Statistical Package for Social Sciences) package program. Each determinant was evaluated by the Variance analysis test and Tukey test to determine whether there was any difference between the groups. A p value less than 0.05 was considered statistically significant.

\section{RESULTS}

The mean age of the cases included in our study was 59.5 years for MM, 54.9 for PAC and 34.1 for RMH; 14 (47\%) of those diagnosed with mesothelioma were female and 16 (53\%) male; $10(33 \%)$ of those diagnosed with adenocarcinoma were female and $20(67 \%)$ male and $7(23 \%)$ of those diagnosed with RMH were female and 23 (77\%) male. 
GLUT-1 antibody was used in a total of 90 patients and staining was positive in $24(80 \%)$ of $30 \mathrm{MM}$ cases, 25 (83.3\%) of 30 PAC cases and in $2(6.6 \%)$ of $30 \mathrm{RMH}$ cases (Table I). GLUT- 1 sensitivity was $80 \%$ and specificity $93.3 \%$ in malignant mesothelioma while the respective figures were $83.3 \%$ and $93.3 \%$ in PAC.

GLUT-1 staining diffuseness was + in $5(16.6 \%),++$ in 9 (30\%), and +++ in 10 (33.3\%) malignant mesothelioma cases (Table I). GLUT-1 staining intensity was ++ in $6(20 \%)$ cases, +++ in $18(60 \%)$ cases, with no positive staining in one case (Figure 1A)

Staining diffuseness was + in $5(16.6 \%),++$ in $4(13.3 \%)$, and +++ in $16(53.3 \%)$ pulmonary adenocarcinoma cases (Table I). GLUT-1 staining intensity was + in $2(20 \%)$ cases, ++ in 6 (20\%) cases and +++ in 17 (56.6\%) cases (Figure 1B).

The diffuseness of GLUT-1staining with was + in $1(3.3 \%)$ reactive mesothelial hyperplasia, ++ in $1(3.3 \%)$, while no +++ staining was seen (Table I). The severity of staining was + in 2 cases $(6.6 \%)$ and no ++ or +++ staining was seen (Figure 1C).

A total of 90 patients included in the study were stained with KOC antibody. Positive staining was found in 25 (83.3\%) of $30 \mathrm{MM}$ cases, 23 (76.6\%) of 30 AAK cases and $14(46.6 \%)$ of $30 \mathrm{RMH}$ cases (Table I). While sensitivity with $\mathrm{KOC}$ was $83.3 \%$ and specificity $53.3 \%$ in $\mathrm{MM}$, and the respective figures were $76.6 \%$ and $53.3 \%$ in pulmonary adenocarcinoma.

KOC staining diffuseness was + in $3(10 \%)$ cases, ++ in $2(6 \%)$ cases, and +++ in $20(66.6 \%)$ cases of malignant mesothelioma (Table I). KOC staining intensity was + in 11 $(36.6 \%)$ cases, ++ in $10(33.3 \%)$ cases, and +++ in $4(13.3 \%)$ cases (Figure 2A).

KOC staining intensity was + in $2(6.6 \%)$ cases, ++6 $(20.3 \%)$ cases, and +++ in $15(50 \%)$ cases with pulmonary adenocarcinoma (Table I). KOC staining intensity was + in $6(20 \%)$ cases, ++ in $14(46.6 \%)$ cases, and +++ in $3(10 \%)$ cases (Figure 2B).

The diffuseness of KOC staining was ++ in $2(6.6 \%)$ reactive mesothelial hyperplasia cases, +++ in 12 (40\%), and no + staining was seen (Table I). KOC staining intensity was + in $1(3.3 \%)$ case, ++ in $4(13.3 \%)$ cases, and +++ in $9(30 \%)$ cases (Figure 2C).

No statistically significant difference was found when MM and PAC cases were compared in terms of GLUT-1 and KOC staining diffuseness and intensity $(\mathrm{p}>0.05)$. However, a statistically significant difference was found $(p<0.05)$ when $\mathrm{MM}$ and PAC cases were compared with RMH cases (Table II).

Table I: The numerical distribution GLUT-1 and KOC staining scores in malignant mesothelioma, lung adenocarcinoma and reactive mesothelial hyperplasia cases

\begin{tabular}{|c|c|c|c|c|c|}
\hline \multirow{2}{*}{$\begin{array}{l}\text { Cases } \\
\text { n (\%) }\end{array}$} & \multirow{2}{*}{ Immunohistochemical Markers } & \multicolumn{4}{|c|}{ Scores } \\
\hline & & $\mathbf{0}$ & $1+$ & $2+$ & $3+$ \\
\hline \multicolumn{6}{|c|}{ Malignant Mesothelioma } \\
\hline $24 / 30(80 \%)$ & GLUT-1 & 6 & 5 & 9 & 10 \\
\hline $25 / 30(83.3 \%)$ & KOC & 5 & 3 & 2 & 20 \\
\hline \multicolumn{6}{|c|}{ Pulmonary Adenocarcinoma } \\
\hline $25 / 30(83.3 \%)$ & GLUT-1 & 5 & 5 & 4 & 16 \\
\hline $23 / 30(76.6 \%)$ & KOC & 7 & 2 & 6 & 15 \\
\hline \multicolumn{6}{|c|}{ Reactive Mesothelial Hyperplasia } \\
\hline $2 / 30(6.6 \%)$ & GLUT-1 & 28 & 1 & 1 & 0 \\
\hline $14 / 30(46.6 \%)$ & KOC & 16 & 0 & 2 & 12 \\
\hline
\end{tabular}

Table II: $\mathrm{p}$ values for the comparison of GLUT-1 and KOC markers in malignant mesothelioma, lung adenocarcinoma and reactive mesothelial hyperplasia (RMH) cases

\begin{tabular}{|l|c|c|c|}
\hline & Mesothelioma - Adenocarcinoma & Mesothelioma - RMH & Adenocarcinoma - RMH \\
\hline GLUT-1 diffuseness & 0.334 & 0.000 & 0.000 \\
\hline GLUT-1 intensity & 0.548 & 0.000 & 0.000 \\
\hline KOC diffuseness & 0.355 & 0.013 & 0.049 \\
\hline KOC intensity & 0.455 & 0.000 & 0.001 \\
\hline
\end{tabular}



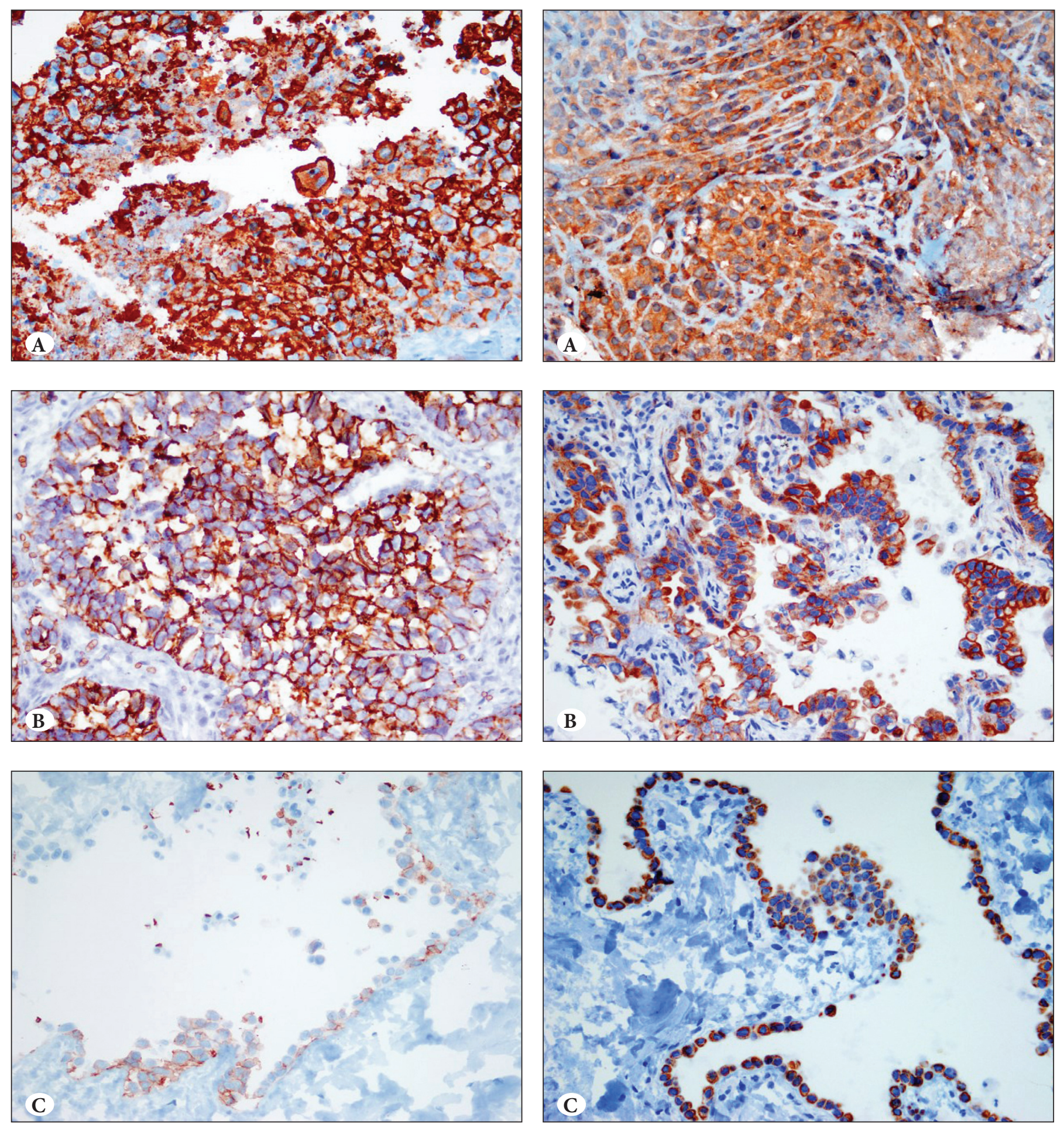

Figure 1: (A) GLUT-1 positivity in malignant mesothelioma (immunoperoxidase, x400), (B) GLUT-1 positivity in pulmonary adenocarcinoma (immunoperoxidase, $\mathrm{x} 400$ ), (C) GLUT-1 positivity in reactive mesothelial hyperplasia (immunoperoxidase, $\mathrm{x} 400$ ).

Figure 2: (A) KOC positivity in malignant mesothelioma (immunoperoxidase, $\mathrm{x} 400$ ), (B) KOC positivity in pulmonary adenocarcinoma (immunoperoxidase, $\mathrm{x} 400$ ), (C) KOC positivity in reactive mesothelial hyperplasia (immunoperoxidase, $\mathrm{x} 400$ ). 


\section{DISCUSSION}

Malignant mesothelioma is a rare tumor developing from serosal surfaces such as the pleura, peritoneum, pericardium, tunica vaginalis testis, and others lining body cavities (2629). Its incidence is increasing rapidly in parallel with the use of asbestos in industrialized countries (30).

The characteristic of malignant mesothelioma is a wide range of histological patterns and cytomorphological features $(31,32)$. MM is pathologically diagnosed with the help of IHC to show the differentiation of "mesothelial", "epithelial" and "sarcomatous" differentiation of the cells that make up the tumor (29). However, there is no consensus on the generally accepted antibody panel to be used in various sub-types of MM at present $(27,29)$.

Mesothelial cell hyperplasia can be caused by infections in the pleural space, collagen vascular diseases, pulmonary infarction, drug reactions, pneumothorax, lung carcinomas located close to the pleura, surgery, trauma, and non-specific inflammation (33-35). RMH can create a pseudoinvasion appearance resembling malignant neoplasm with increased cellularity, cytological atypia, numerous mitotic figures, necrosis, and entry of mesothelial cells into fibrous tissue $(33,34)$. IHC methods should therefore be used as it can be difficult to differentiate benign and malignant mesothelial proliferations by morphology alone, especially in small biopsy samples and in cases where stromal invasion cannot be clearly evaluated $(31,33,34)$. However, there is no generally accepted IHC marker for the differentiation of $\mathrm{MM}$ and $\mathrm{RMH}$ at present (10,36-38).

Warburg found the proliferation of cancer cells to be an energy-related process supported by glucose metabolism approximately 80 years ago. The increase in glucose use to meet the high energy need in malignant cells requires an increase in carrier proteins. GLUT-1 in particular is responsible for the passage of glucose into the cell in many tumors (11).

GLUT-1 secretion can be seen in carcinomas developing from various organs such as the breast, head and neck, bladder and kidney (10). GLUT-1 positivity in reactive mesothelial hyperplasia was reported to be $0 \%$ by Afify et al. (39), $3 \%$ by Zimmermann et al. (40), and $20 \%$ by Burstein et al. (41). Kato et al. (10) found GLUT-1 staining in none of the $40 \mathrm{RMH}$ cases, and in all $48 \mathrm{MM}$ cases in their study (10). A study conducted at the University of Chicago reported GLUT-1 staining in none of the 40 benign mesothelial proliferation (20 normal, 20 reactive) cases, and weak to strong staining in 46 (80\%) of $55 \mathrm{MM}$ cases (42). Our study findings showed a significant difference between MM and RMH cases in terms of GLUT-1 staining diffuseness and intensity.

KOC, commonly known as IMP3 in the literature, is another IHC marker reported to be sensitive and specific for the differentiation of RMH and MM, in addition to GLUT-1 $(20,34)$. It was first found in pancreatic carcinoma cells and later reported to be secreted in many malignant tumors in humans $(20,31)$. The IMP family plays an important role in the regulation of cell growth, differentiation, and apoptosis, and increased IMP secretion starts neoplastic cell proliferation (31).

There are a few studies reporting IMP3 to be a useful marker in the differentiation of MM and $\mathrm{RMH}$ in surgical materials (20,34). Sojka et al. (43) found IMP3 positivity in $72.7 \%$ of malignant pleural mesothelioma cases and no IMP3 staining in normal mesothelial cells. Xu et al. (44) analyzed IMP3 secretion in biopsies containing malignant pleural mesothelioma, simple mesothelial hyperplasia and atypical mesothelial hyperplasia and reported that samples containing simple mesothelial hyperplasia did not stain with IMP3 while $64 \%$ of malignant pleural mesothelioma cases showed staining (44).

A significant difference was found between RMH and MM cases in terms of the KOC staining diffuseness and intensity in our study $(\mathrm{p}<0,05)$. Although KOC positivity was higher than GLUT-1 positivity in MM cases, GLUT-1 is thought to be a useful marker in the differentiation of $\mathrm{MM}$ and $\mathrm{RMH}$ due to the lower specificity of KOC for MM.

KOC positivity is not $100 \%$ specific for a diagnosis of malignancy. Studies have shown KOC positivity with other conditions causing mesothelial cell regeneration and proliferation (31). In fact, while KOC was negative in simple mesothelial hyperplasia composed of a single row of mesothelial cells, moderate $(++)$ and severe $(+++)$ KOC positivity was found in 14 RHM cases $(46.6 \%)$ accompanied by intense inflammation in our study.

Epithelioid type MM can be confused with PAC as it shows a wide range of patterns with the tubulopapillary and solid types being most common. IHC methods should be used for the differential diagnosis as morphological findings are not adequate (7). When we take the sensitivity and specificity into account, the best positive mesothelioma markers are calretinin, cytokeratin $5 / 6$, podoplanin and WT- 1 , and the best positive carcinoma markers are MOC31, Ber-EP4, B72.3, CEA, BG-8 and TTF-1. The use of two positive mesothelioma markers and two positive carcinoma markers is recommended for the differentiation of epithelioid mesothelioma and PAC (32). 
Our study found no significant difference between MM and $\mathrm{RMH}$ cases in terms of the diffuseness and intensity of GLUT-1 staining $(p<0.05)$. This result is similar to the literature, indicating that GLUT-1 is not useful in MM and PAC differentiation.

There is little information in the literature on IMP secretion in pulmonary adenocarcinoma (20). The recent study by Bellezza et al. (45) evaluated 126 cases of non-small cell lung carcinoma and found positive IMP 3 staining in 55\% of nonsmall cell lung carcinomas and in 25\% of bronchoalveolar carcinoma cases. Jennifer et al. (20) found IMP3 staining in 29 of 41 moderate and poorly differentiated adenocarcinoma cases, 4 of 10 bronchoalveolar carcinoma cases and 14 of 25 well differentiated adenocarcinoma cases. Our study found no significant difference between $\mathrm{MM}$ and $\mathrm{RMH}$ cases in terms of KOC staining diffuseness and intensity $(\mathrm{p}<0,05)$.

We therefore concluded that GLUT-1 and KOC markers were not useful for the differentiation of MCC and PAC but could be of great benefit in differentiating RMH from MM and PAC.

\section{REFERENCES}

1. Gümürdülü D, Zeren H, Cagle P, Kayaselçuk F, Alparslan $N$, Kocabaş A, Tuncer I: Specificity of MOC-31 and HBME1 immunohistochemistry in the differential diagnosis of adenocarcinoma and malignant mesothelioma: A study on environmental malignant mesothelioma cases from Turkish Villages. Pathol Oncol Res 2002, 8:188-193

2. Deniz H, Kibar Y, Güldür ME, Bakır K: Is D2-40 a useful marker for distinguishing malignant mesothelioma from pulmonary adenocarcinoma and benign mesothelial proliferations? Pathol Res Pract 2009, 205:749-752

3. Wagner JC, Sleegs CA, Marchand P: Diffuse pleural mesothelioma and asbestos exposure in the North Western Cape Province. Br J Med 1960; 17:260-271

4. Aydıner F, Yerci Ö: Malign mezotelyoma ve primer akciğer adenokarsinomu ayırıcı tanısında immünhistokimyasal analiz. Turk Patoloji Derg 2004, 20:60-65

5. Ordonez NG: The immunohistochemical diagnosis of mesothelioma: A comparative study of epithelioid mesothelioma and lung adenocarcinoma. Am J Surg Pathol 2003, 27:1031-1051

6. King JE, Thatcher N, Pickering C, Hasleton PS: Sensitivity and specificity of immunohistochemical markers used in the diagnosis of epithelioid mesothelioma: A detailed systematic analysis using published data. Histopathology 2006, 48:223-232

7. Akyıldız Ë̈, Öz B, Akı H, Demirkaya A: Plevral epiteloid malign mezotelyoma ile adenokarsinom ayırıcı tanısında immünhistokimya; bir panel önerisi. Türk Toraks Dergisi 2010, 11:144-148

8. Tot T: The value of cytokeratins 20 and 7 in discriminating metastatic adenocarcinomas from pleural mesotheliomas. Cancer 2001, 92:2727-2732
9. Elagöz Ş, Ĕ̆ilmez $R$, Aker H: Plevra biyopsilerinde; reaktif mezotel hiperplazisi, malign mezotelyoma ve adenokarsinom metastazının ayırıcı tanısında immünhistokimya (CEA) ve AgNOR metodunun değeri. Turk Patoloji Derg 1999, 1:8-12

10. Kato Y, Tsuta K, Seki K, Maeshima AM, Watanabe S, Suzuki K, Asamura H, Tsuchiya R, Matsuno Y: Immunohistochemical detection of GLUT-1 can discriminate between reactive mesothelium and malignant mesothelioma. Mod Pathol 2007, 20: 215-220

11. Dağlı AF, Özercan MR: Endometriumun benign, premalign ve malign lezyonlarında Glut-1 ile Ki-67'nin ayırıcı tanıdaki yeri. Firat Tip Dergisi 2006, 11:93-97

12. Legan M, Tevzic S, Tolar A, Luzar B, Marolt VF: Glukoz transporter-1 (GLUT-1) immunoreactivity in benign, premalignant and malignant lesions of the gallbladder. Pathol Oncol Res 2010, 10:9281-9287

13. Younes M, Brown RW, Stephenson M, Gondo M, Cagle PT: Overexpression of Glut1 and Glut3 in stage1 nonsmall cell lung carcinoma is associated with poor survival. Cancer 1997, 80: 1046-1051

14. Ohba S, Fujii H, Ito S, Fujimaki M, Matsumoto F, Furukawa M, Yokoyama J, Kusunoki T, Ikeda K, Hino O: Overexpression of GLUT-1 in the invasion front is associated with depth of oral squamous cell carcinoma and prognosis. J Oral Pathol Med 2010, 39:74-78

15. Suganuma N, Segade F, Matsuzu K, Bowden DW: Differential expression of facilitative glucose transporters in normal and tumour kidney tissues. BJU Int 2007, 99:1143-1149

16. William A, Ahrens MD, Ridenour R, Caron BL, Miller DV, Folpe AL: GLUT-1 expression in mesenchymal tumors: An immunohistochemical study of 247 soft tissue and bone neoplasms. Hum Pathol 2008, 39:1519-1526

17. Kojika M, Ishii G, Yoshida J, Nishimura M, Hishida T, Ota SJ, Murata Y, Nagai K, Ochiai A: Immunohistochemical differential diagnosis between thymic carcinoma and type B3 thymoma: Diagnostic utility of hypoxic marker, GLUT-1, in thymic epithelial neoplasms. Mod Pathol 2009, 22:1341-1350

18. Sung JY, Kim GY, Lim SJ, Park YK, Kim YW: Expression of the GLUT1 glucose transporter and p53 in carcinomas of the pancreatobiliary tract. Pathol Res Pract 2010, 206:24-29

19. Airley R, Evans A, Mobasheri A, Hewitt SM: Glucose transporter Glut-1 is detectable in peri-necrotic regions in many human tumor types but not normal tissues: study using tissue microarrays. Ann Anat 2010, 192:133-138

20. Findeis-Hosey JJ, $\mathbf{X} \boldsymbol{H}$ : The use of insulin like-growth factor II messenger RNA binding protein-3 in diagnostic pathology. Hum Pathol 2011, 42:303-314

21. Li S, Cha J, Kim J, Kim KY, Kim HJ, Nam W, Cha IH: Insulinlike growth factor 2 mRNA-binding protein 3: A novel prognostic biomarker for oral squamous cell carcinoma. Head Neck 2011 33:368-374

22. Righi A, Zhang S, Jin L, Scheithauer BW, Kovacs K, Kovacs G, Goth MI: Korbonits M, Lloyd RV. Analysis of IMP3 expression in normal and neoplastic human pituitary tissues. Endocr Pathol 2010, 21:25-31 
23. Pryor JG, Simon RA, Bourne PA, Spaulding BO, Scott GA, $\boldsymbol{X} \boldsymbol{u} \boldsymbol{H}$ : Merkel cell carcinoma expresses $\mathrm{K}$ homology domaincontaining protein overexpressed in cancer similar to other highgrade neuroendocrine carcinomas. Hum Pathol 2009, 40:238-243

24. Jiang Z, Lohse CM, Chu PG, Wu CL, Woda B, Rock K, et al: Oncofetal protein IMP3: A novel molecular marker that predicts metastasis of papillary and chromophobe renal cell carcinomas. Cancer 2008, 112:2676-2682

25. Ikenberg $K$, Fritzsche FR, Zuerrer-Haerdi U, Hofmann I, Hermanns T, Seifert H, Müntener M, Provenzano M, Sulser T, Behnke S, Gerhardt J, Mortezavi A, Wild P, Hofstädter F, Burger M, Moch H, Kristiansen G: Insulin-like growth factor 2 mRNA binding protein 3 (IMP3) is overexpressed in prostate cancer and correlates with higher gleason scores. BMC Cancer 2010, 10:341

26. Churg A, Roggli V, Cagle PT, Gibbs AR, Hasleton PS, Henderson DW, et al: Mesothelioma. Travis WD, Brambilla E, MüllerHermelink HK, Harris CC. (Eds): World Health Organization Classification of Tumours Pathology and Genetics: Tumours of the Lung, Pleura, Thymus and Heart, Lyon, IARC pres 2004: 125-144

27. Dağlı AF: Diffüz plevral malign mezotelyomada patolojik tanı ve ayırıcı tanı. Türkiye Klinikleri Tip Bilimleri Dergisi 2011, 4(1): $50-57$

28. Inai K: Pathology of mesothelioma. Environ Health Prev Med 2008, 13:60-64

29. Marchevsky AM: Application of immunohistochemistry to the diagnosis of malignant mesothelioma. Arch Pathol Lab Med 2008, 132:397-401

30. Burdorf A, Jarvholm B, Englund A: Explaining differences in incidence rates of pleural mesothelioma between Sweden and the Netherlands. Int Cancer 2005,113:298

31. Hanley KZ, Facik MS, Bourne PA, Yang Q, Spaulding BO, Bonfiglio TA, $\boldsymbol{X} \boldsymbol{u} H$ : Utility of anti-L523S antibody in the diagnosis of benign and malignant serous effusions. Cancer 2008, 114:49-56

32. Ordonez NG: What are the current best immunohistochemical markers for the diagnosis of epithelioid mesothelioma? A review and update. Hum Pathol 2007, 38:1-16

33. Moore KL, Persaud TV, Torchia MG: İnsan Embriyolojisi. Dalçık H, Yıldırım M (Çeviren) s.202-204, İstanbul, Nobel Tıp Kitabevleri, 2009

34. Ikeda K, Tate G, Suzuki T, Kitamura T, Mitsuya T: IMP3/L523S, a novel immunocytochemical marker that distinguishes benign and malignant cells: The expression profiles of IMP3/L523S in effusion cytology. Hum Pathol 2010, 41:745-750

35. King J, Thatcher N, Pickering C, Hasleton P: Sensitivity and specificity of immunohistochemical antibodies used to distinguish between benign and malignant pleural disease: A systematic review of published reports. Histopathology 2006, 49: 561-568

36. Taheri ZM, Mehrafza M, Mohammadi F, Khoddami M, Bahadori M, Masjedi MR: The diagnostic value of Ki-67 and repp86 in distinguishing between benign and malignant mesothelial proliferations. Arch Pathol Lab Med 2008, 132: 694-697
37. Comin CE, Novelli L, Boddi V, Paglierani M, Dini S: Calretinin, thrombomodulin, CEA and CD15: Useful combination of immunohistochemical markers for differentiating pleural epithelial mesothelioma from peripheral pulmonary adenocarcinoma. Hum Pathol 2001, 32: 529-536

38. Sandeck HP, Roe OD, Kjaerheim K, Willen H, Larsson E: Re-evalution of histological diagnoses of malignant mesothelioma by immunohistochemistry. Diagn Pathol 2010, 5:47

39. Afify A, Zhou H, Howell L, Paulino AF: Diagnostic utility of Glut-1 expression in the cytologic evaluation of serous fluids. Acta Cytol 2005, 49: 621-626

40. Zimmerman RL, Goonewardene S, Fogt F: Glucose transporter Glut-1 is of limited value for detecting breast carcinoma in serous effusions. Mod Pathol 2001, 14:748-751

41. Burstein DE, Reder I, Weiser K, Tong T, Pritsker A, Haber RS: GLUT-1 glucose transporter: A highly sensitive marker of malignancy in body cavity effusions. Mod Pathol 1998, 11: 392-396

42. Actuaria A, Arif Q, Gattuso P, McIntere M, Krausz T, Husain $A N$ : Value of immunohistochemical markers in differentiating benign from malignant mesothelial lesions. Lab Invest 2008, 88 (Supp 1): 334A

43. Sojka KM, Spaulding B, Nielsen GK, Dinnogen SA, Dinnogen $S A$, Welcher R: Immunoreactivity of anti-L523S on normal and malignant lung pleural tissue biopsies. Lab Invest 2006, 86 (Supp 1): 317A

44. $X u H$, Simon $R$, Bourne PA, Spaulding BO, Wang $H L$ : Immunohistochemical analysis of KOC/IMP3 in malignant pleural mesothelioma. Mod Pathol 2008, 21:353

45. Bellezza G, Cavaliere A, Sidoni A: IMP3 expression in non-small cell lung cancer. Hum Pathol 2009, 40:1205-1206 